\title{
The Analysis of Noise Level of RGB Image Generated Using SOM
}

\author{
Sergejs Kodors ${ }^{1}$, Peter Grabusts ${ }^{2}{ }^{1-2}$ Rezekne Higher Education Institution
}

\begin{abstract}
The article discusses how to generate RGB images with noise using Kohonen's self-organizing map (SOM). The article also describes the adaptation process and structure of SOM, which can be used to generate RGB images with noise. The authors of the article evaluate the influence of SOM parameters (a learning coefficient, adaptation time, effective width) on the noise level of RGB image generated using SOM. According to these observations, the authors formulate several recommendations how to control the noise level by adjusting SOM parameters.
\end{abstract}

Keywords - additive noise, image generation, self-organizing map

\section{INTRODUCTION}

The cross-validation method is used to determine the neural network ability to recognize the images [2]. According to the cross-validation method, the total array of images is divided into two groups: a validation set and an estimation set. The estimation set includes the images, which are used during the adaptation process of SOM, but the validation set comprises the images, which are not used during the adaptation process of SOM.

The neural network ability to recognize the images is determined as the ratio of the recognized images from the validation set. Therefore, the larger the validation set is, the more accurate the result is.

However, to determine the neural network ability to recognize the images with noise, the validation set must contain the images with noise. If there are only the images without noise, there is need for an automatic system to generate the images with noise.

SOM can be used to generate RGB images with noise for the validation process.

The aim of this research is to investigate the influence of SOM parameters (a learning coefficient, adaptation time, effective width) on the noise level of RGB image generated using SOM. This analysis will enable the authors of the article to develop the recommendations on how to control the noise level of RGB image by adjusting SOM parameters.

\section{KOHONEN'S SELF-ORGANIZING MAP}

SOM is a neural network with a feature to configure the neurons so that the close neurons begin to react to the similar signals [2], [6].

SOM consists of the following elements:

- the adaptation time - the step count of the adaptation process;
- the SOM lattice - the structure of SOM, where the neurons are placed in the nodes or cells. The lattice can be one-dimensional or multidimensional;

- the winning neuron - the neuron with a minimal distance to an input signal;

- the learning coefficient - the SOM parameter, which determines a learning speed in every step of the adaptation process;

- the topological neighbourhood - a mathematical function, which determines the influence field with a winning neuron in its centre;

- the effective width - the parameter of topological neighbourhood, which affects the topological neighbourhood width.

\section{The Adaptation Process of Self-Organizing MaP}

The adaptation process of SOM is based on the competitive learning, when the neurons compete among themselves, which is more similar to an input signal [2]-[3], [4], [6]-[7]:

1. Initial learning coefficient $\eta_{0}$ is inputted.

2. Adaptation time $t$ is inputted.

3. Initial effective width $\delta_{0}$ is inputted.

4. Random values to the neuron weights are generated.

5. Random input signal $x$ is generated.

6 . The winning neuron $i(x)$ is determined by Euclidean distance (1):

$$
i(x)=\arg \min _{j}\left\|x-w_{j}\right\|,
$$

where $j$ - the neuron, $w_{j}-j$ neuron weights.

7. All neurons are adapted by the formula (2):

$w_{j}(n)=w_{j}(n-1)+\eta(n) \cdot h_{j, i(x)}(n) \cdot\left(x-w_{j}(n-1)\right)$

where $n$ - the adaptation step, $h_{j, i(x)}(n)$ - the topological neighbourhood.

8. 5-7 steps are repeated $t-1$ times.

To calculate the topological neighbourhood $h_{j, i(x)}(n)$, any mathematical function can be used, which satisfies these conditions [2]:

- the function is symmetric at the winning neuron;

- the function decreases, when the distance to the winning neuron increases, but it never achieves zero.

Gaussian function satisfies these conditions (3).

$$
h_{j, i(x)}=\exp \left(\frac{d^{2}}{2 \cdot \delta^{2}(n)}\right),
$$

where $d$ - the Euclidean distance from neuron $j$ to the winning neuron, $\delta$ - the effective width. 
The learning coefficient and effective width must decrease for the adaptation process; to satisfy this condition, it is recommended to use the following formulas [2]:

$$
\eta(n)=\eta_{0} \cdot \exp \left(-n / \tau_{1}\right)
$$

where $\tau_{1}$ - some coefficient, $n-$ the adaptation step.

$$
\delta(n)=\delta_{0} \cdot \exp \left(-n / \tau_{2}\right)
$$

where $\tau_{2}$ - some coefficient, $n$ - the adaptation step.

The learning step $n$ is calculated beginning with zero, then the first adaptation step contains these values: $\eta(0)=\eta_{0}$ and $\delta(0)=\delta_{0}$.

The adaptation process of SOM consists of two phases: the organization of neurons and the stabilization process of values. It is recommended to use particular values of parameters for every phase [2].

The organization process of neurons:

- the learning coefficient: $\eta_{0}=0.1$ and $\tau_{1}=1000$;

- the effective width has such a value that the initial topological neighbourhood practically influences all neurons;

- the adaptation time: 1000 steps.

The stabilization process of values:

- the learning coefficient is static and equal to 0.01 ;

- the effective width has such a value that the topological neighbourhood only influences adjacent neurons;

- the adaptation time is approximately 500 times larger than the number of neurons.

\section{RGB IMAGE GENERATION USING SELF-ORgANIZING MAP}

Every synapse (weight) of a neuron can only get one value, therefore RGB image (an input signal) must be transformed into the one-dimensional array to obtain the association of the neuron weights with an input signal.

The one-dimensional array size is $3 \cdot n \cdot m$, where $n-$ the image width, $m-$ the image height.

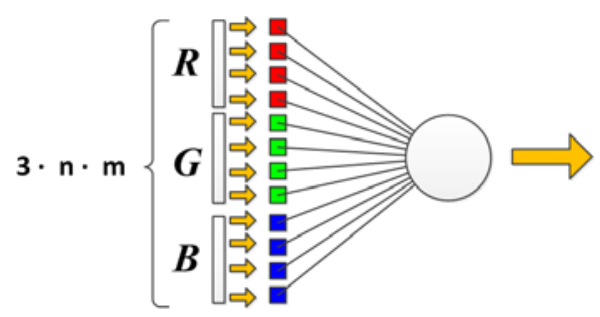

Fig. 1. The association of RGB image with neurons weights

To create the association of the neuron weights with the input signal the following concept can be used: the first $n \cdot m$ elements are associated with red colour components of the RGB image, the next $n \cdot m$ elements - with green colour components, and the remaining ones - with blue colour components. To distinguish the image rows, for every colour group (the group size is $n \cdot m$ elements, where $m$ is the number of rows) the following concept is used: the first $n$ elements are associated with the first image row, the second - with the second row and so on for each colour group. The sketch of this association is illustrated in Fig. 1.

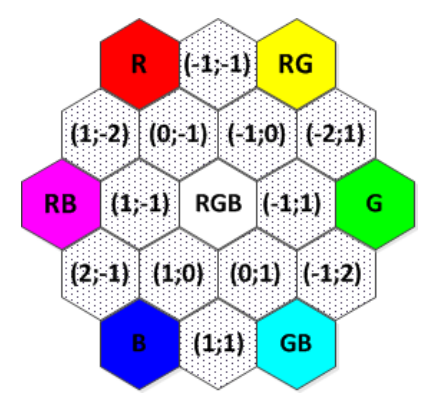

Fig. 2. The hexagonal SOM to generate RGB images with noise

To generate RGB images with noise, the following feature of SOM is used: the winning neuron weights aim to be equal to an input signal, but adjacent neuron weights aim to be equal to the winning neuron weights. Therefore, the input signal is selected from the array $\{R G B, R G, G B, R B, R, G, B\}$, where the letters indicate unturned colour components of the generated image (other elements of the image are equal to zero).

If there is a need to generate an equal number of the images, which are inclined to some colour, a hexagonal type of the lattice with the predefined winning neurons can be used: the central neuron weights are equal to the generated image colour values (to input signal $R G B$ ), the corner neuron weights are equal to inputs $\{R, R G, G, G B, B, R B\}$. Other neuron weights have the random values (see Fig. 2).

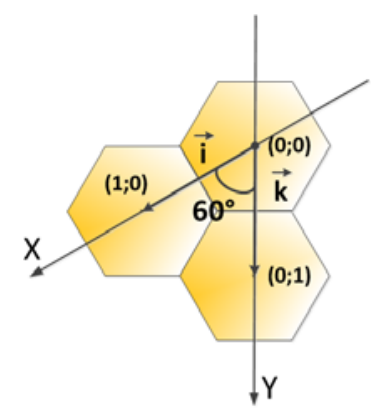

Fig. 3. The coordinates of the hexagonal lattice

Than RGB images with noise are generated among the predefined winning neurons.

The distance between two neurons of the hexagonal SOM is calculated by the formula (6).

$$
\Delta d=\sqrt{\Delta a^{2}+\Delta b^{2}+\Delta a \cdot \Delta b},
$$

where $\Delta a$ - the distance between two neurons on the coordinate $X, \Delta b-$ on the coordinate $Y$, and $60^{\circ}$ between the coordinates (see Fig. 3).

\section{AdDitive NoISE OF RGB IMAGE}


The additive noise is the signal, which is added to the original signal [1]. If the original image pixel value is represented as (7), then the pixel value with the additive noise is represented as (8).

$$
C=(r, g, b)
$$

where $r$ - the red colour component, $g$ - green, $b$ - blue.

$$
C^{\prime}=(r+\Delta r, g+\Delta g, b+\Delta b) \text {. }
$$

Then the noise level can be calculated as the mean square error (9) [5].

$$
M S E=\sum_{i=0}^{n-1} \sum_{j=0}^{m-1} \frac{\Delta r_{i j}^{2}+\Delta g_{i j}^{2}+\Delta b_{i j}^{2}}{3 \cdot n \cdot m},
$$

where $n$ - the image width, $m$ - the image height.

The initial noise level of the images of the neurons with the random weights can be calculated as the expected value of the distance between two pixels, between the same colour components. This regularity (10) may be seen in Fig. 4.

\begin{tabular}{|c|c|c|c|c|c|c|}
\hline diagonal & 256 & 255 & $\ldots$ & 3 & 2 & 1 \\
\hline value & 0 & 1 & $\ldots$ & 253 & 254 & 255 \\
\hline 0 & $Q$ & $1^{2}$ & $\ldots$ & $253^{2}$ & $254^{2}$ & $255^{2}$ \\
\hline 1 & $(-1)^{2}$ & 0 & & $252^{2}$ & $253^{2}$ & $254^{2}$ \\
\hline$\ldots$ & $\ldots$ & $\ldots$ & $\ldots$ & & $\ldots$ & $\ldots$ \\
\hline 253 & $(-253)^{2}$ & $(-252)^{2}$ & $\ldots$ & 0 & $1^{2}$ & $2^{2}$ \\
\hline 254 & $(-254)^{2}$ & $(-253)^{2}$ & $\ldots$ & $(-1)^{2}$ & $Q$ & $1^{2}$ \\
\hline 255 & $(-255)^{2}$ & $(-254)^{2}$ & $\ldots$ & $(-2)^{2}$ & $(-1)^{2}$ & 0 \\
\hline
\end{tabular}

Fig. 4. All variations of the distance

$$
\mu=2 \cdot \sum_{i=1}^{255} \frac{(256-i)^{2} \cdot i}{256^{2}}=10922.5
$$

where $\mu$ - the expected value of the distance.

\section{SElf-Organizing MAP AND NoISE LEVEL}

The aim of this research is to investigate the influence of SOM parameters on the noise level of RGB image generated by SOM. This analysis will enable the authors of the article to formulate recommendations on how to control the noise level by adjusting SOM parameters.

Within the framework of the research, the following SOM parameters have been analysed:

- the learning coefficient;

- the adaptation time;

- the effective width.

The effective width is determined through the initial distance and the initial topological neighbourhood function value in the analysis process (11).

$$
\delta(d, h)=\frac{d}{\sqrt{2 \cdot \ln \left(h^{-1}\right)}},
$$

where $d$ - the initial distance, $h$ - the initial topological neighbourhood function value.

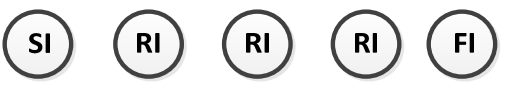

Fig. 5. The experiment model

$S I$ - the neuron with the weights, which are equal to the generated image (it is the random image in the experiment); $R I$ - the neurons with the random weights (all 3 neurons are equal); $F I$ - the neuron with the weights, which are equal to the filtered image by the colour: one group by the red colour, other by the green-blue colour (see Fig. 5).

The first $R I$ describes the neurons, which are closer to $S I$, the second $R I$ describes the neurons between $S I$ and $F I$, and the third $R I$ - which are closer to $F I$.

The same set of $S I$ and $R I$ images and the same sequence of winning neurons have been used in every observation of the experiment; all these elements have been generated before the experiment.

The experiment factors are displayed in Table I.

The static parameters have been taken according to [2] recommendations.

The results of the experiments are illustrated in Fig. 6-10.

The experiment with 5 neurons of SOM has shown the relation: the neurons before the middle neuron and after it; therefore the SOM experiment has been extended to 7 neurons (see Fig. 10).

The extension to 7 neurons allows observing how the neurons behave, when they approach the middle neuron. Fig. 10a-10b describe direction from $S I$ to the middle neuron;

\begin{tabular}{|c|c|c|c|c|}
\hline Image size: & \multicolumn{4}{|l|}{$10 \times 10$} \\
\hline Count of observations: & \multicolumn{4}{|l|}{100} \\
\hline SOM parameters & Range & Step & \multicolumn{2}{|c|}{ Static parameters } \\
\hline Learning coefficient $\eta_{0}$ & $0.001-0.01$ & 0.001 & \multirow{3}{*}{$\begin{array}{c}\delta_{0}(d=4, h=0.1) \\
t=1000\end{array}$} & \multirow{5}{*}{$\begin{array}{l}\tau_{1}=1000 \\
\tau_{2}=1000\end{array}$} \\
\hline Learning coefficient $\eta_{0}$ & $0.01-0.2$ & 0.01 & & \\
\hline Learning coefficient $\eta_{0}$ & $0.2-3$ & 0.1 & & \\
\hline Adaptation time $t$ & $100-2000$ & 100 & $\begin{array}{c}\eta_{0}=0.1 \\
\delta_{0}(4,0.1)\end{array}$ & \\
\hline Effective width $\delta_{0}$ & $d \in[1 ; 7]$ & 1 & $\begin{array}{c}h=0.1, \eta_{0}=0.1 \\
t=1000\end{array}$ & \\
\hline
\end{tabular}
Fig. 10d-10e describe direction from FI to the middle neuron; Fig. 10c - the middle neuron.

TABLE I

EXPERIMENT PARAMETERS 


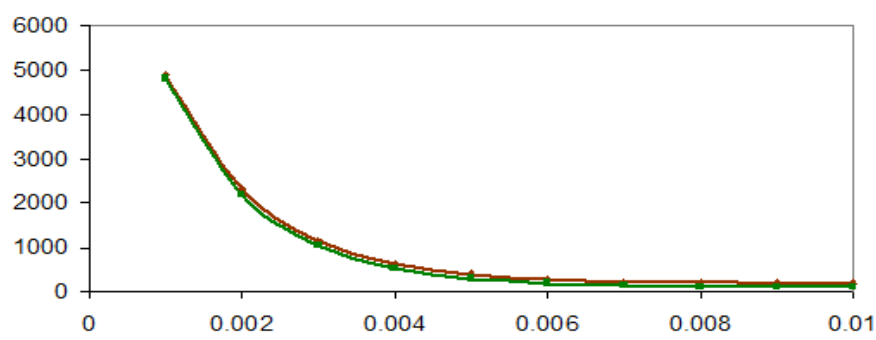

(a)

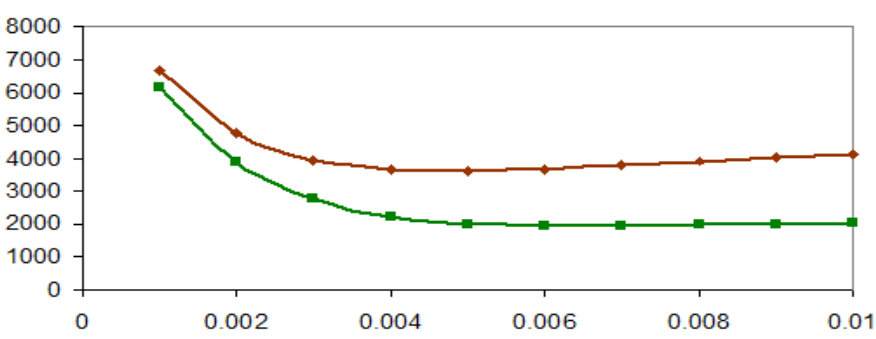

(b)

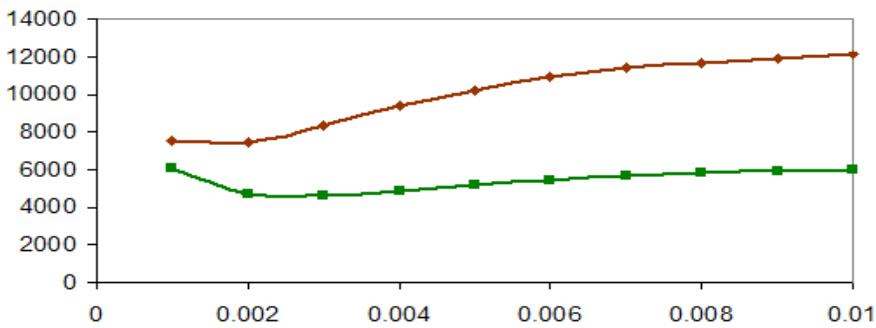

(c)

Fig. 6. The pit-effect of the learning coefficient and the noise level. (a) - the first $R I$ neuron from $S I$, (b) - the second, (c) - the third, where $X$ axis is the learning coefficient, $Y$ - the noise level, where the top line is the red colour $F I$, the bottom - the green-blue colour $F I$

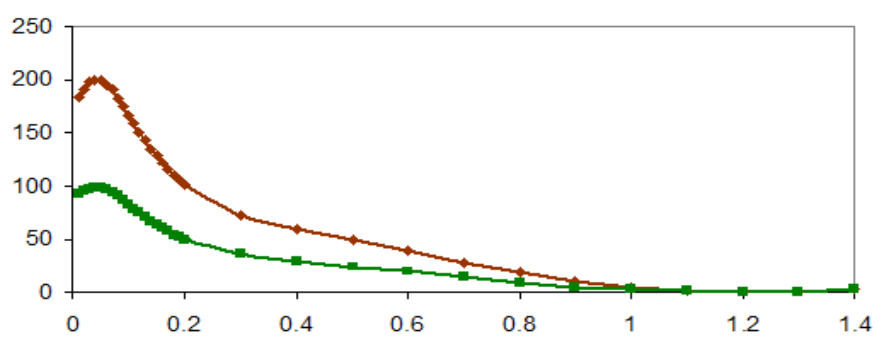

(a)

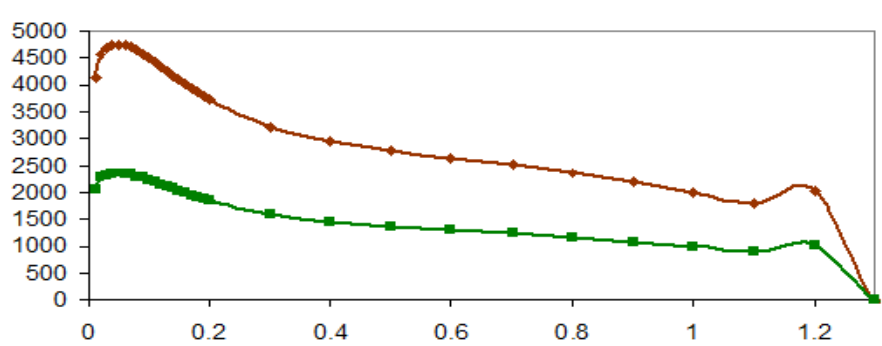

(b)

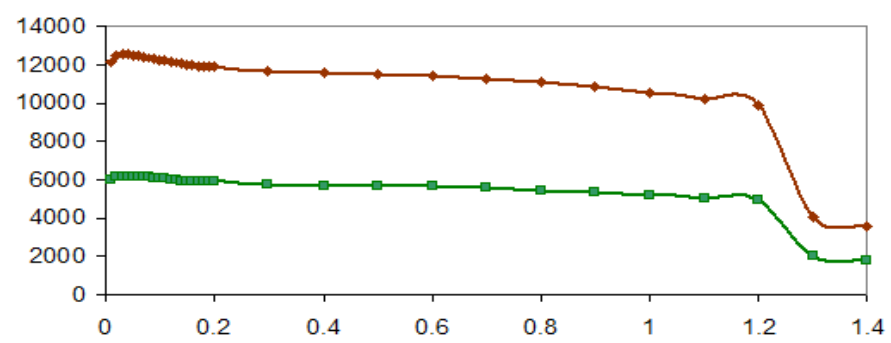

(c)

Fig. 7. The decrease in the learning coefficient and stable noise. (a) - the first $R I$ neuron from $S I$, (b) - the second, (c) - the third, where $X$ axis is the learning coefficient, $Y$ - the noise level, where the top line is the red colour $F I$, the bottom - the green-blue colour $F I$

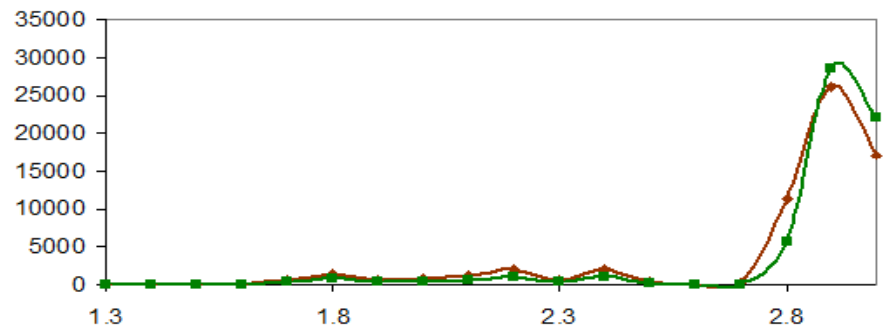

(a)

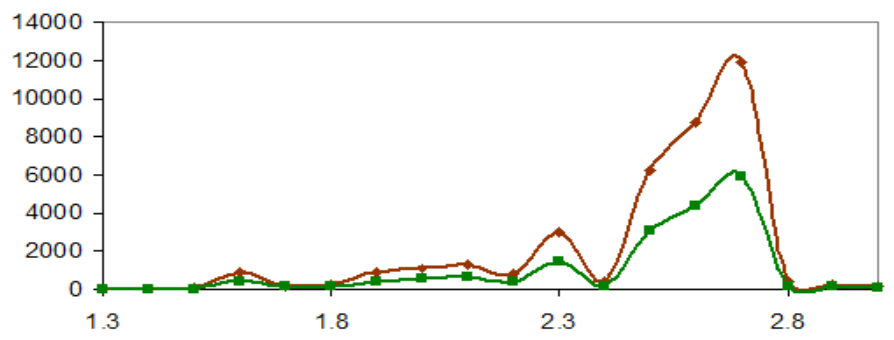

(b)

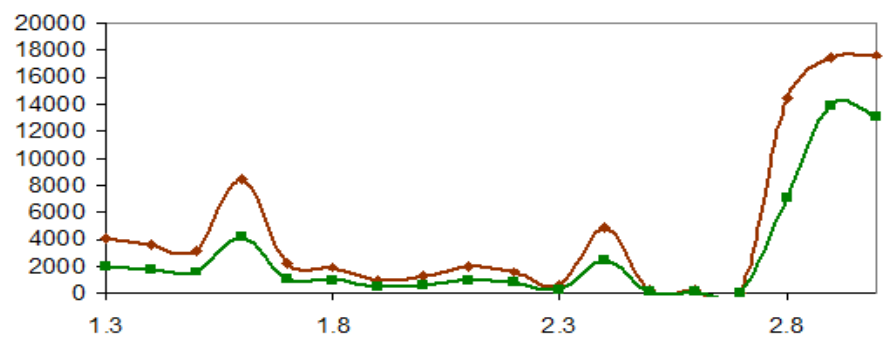

(c)

Fig. 8. The learning coefficient, the unstable range (a) - the first $R I$ neuron from SI, (b) - the second, (c) - the third, where $X$ axis is the learning coefficient, $Y$ - the noise level, where the top line is the red colour FI, the bottom - the green-blue colour $F I$ 


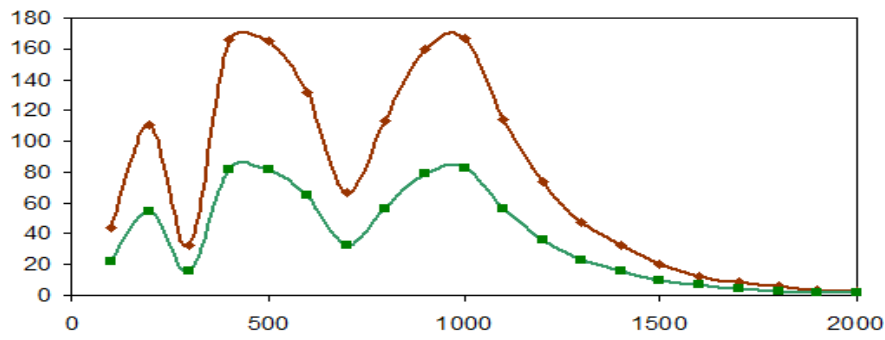

(a)

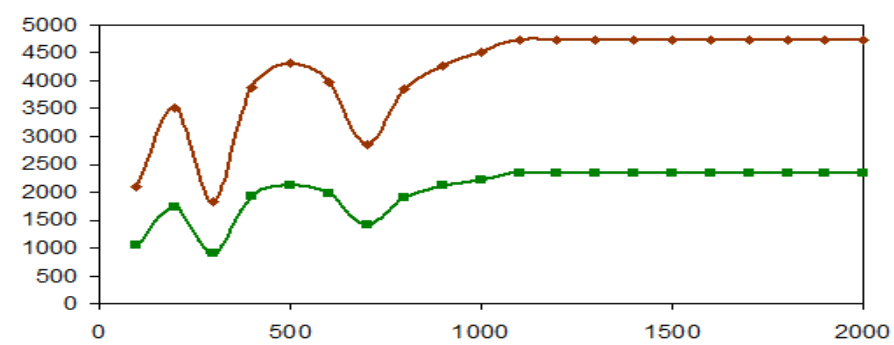

(b)

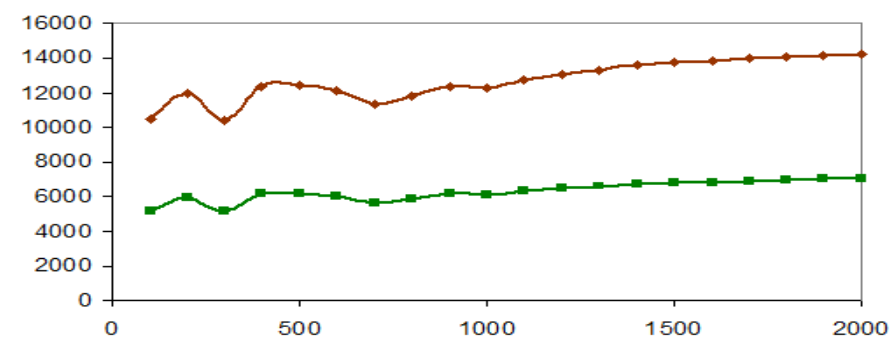

(c)

Fig. 9. The adaptation time. (a) - the first $R I$ neuron from $S I$, (b) - the second, (c) - the third, where $X$ axis is the adaptation time, $Y$ - the noise level, where the top line is the red colour $F I$, the bottom - the green-blue colour FI

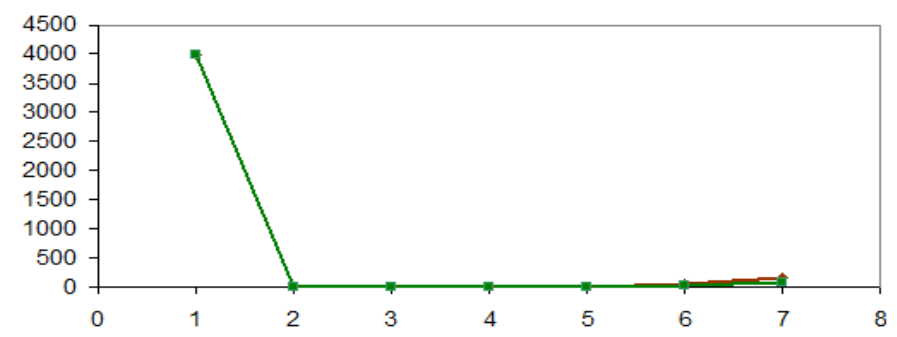

(a)

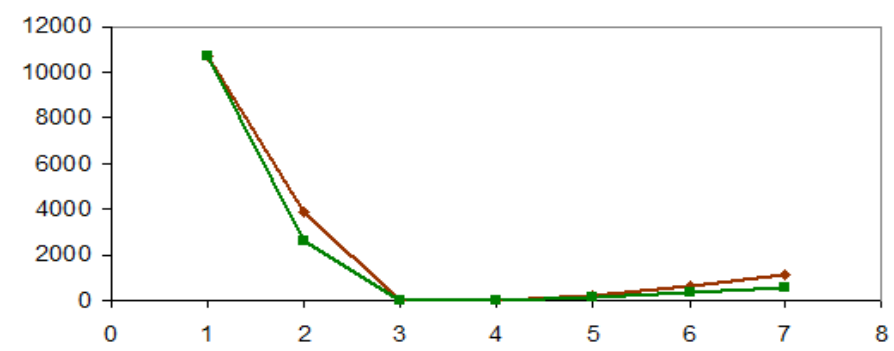

(b)

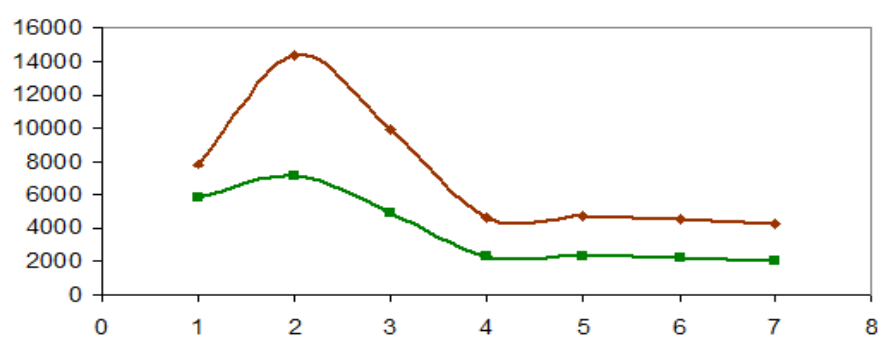

(c)

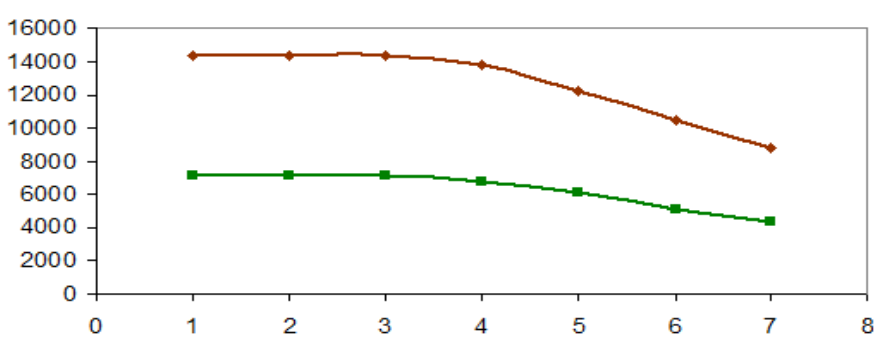

(d)

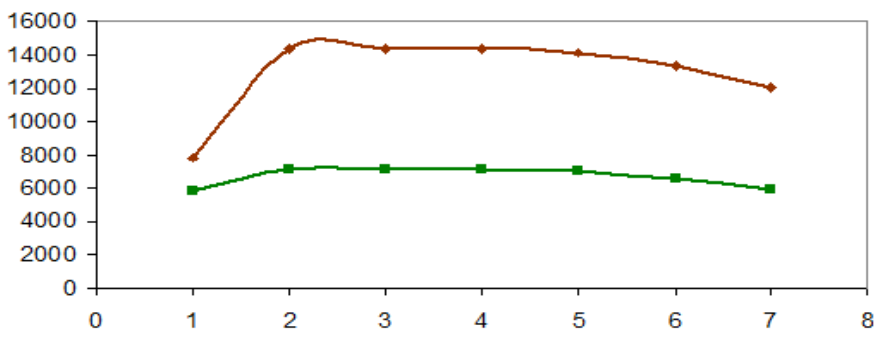

(e)

Fig. 10. The effective width. (a) - the first $R I$ neuron from $S I$, (b) - the second, (c) - the third, (d) - the fourth, (e) - the fifth, where $X$ axis is the effective width, $Y$ - the noise level, where the top line is the red colour $F I$, the bottom - the green-blue colour $F I$

\section{CONCLUSIONS AND RECOMMENDATIONS}

Despite initial different distances (MSE) between SI and FI of 2 groups (filtered by the red and green-blue colour), the result graphs change identically (see Fig. 6-10). There are the differences in the noise level: the less the initial distance is, the less the resulting noise level is.

The noise level goes through 3 phases while the learning coefficient $\eta_{0}$ changes:

- the noise level makes a small pit, when the learning coefficient is too small $\left(\eta_{0} \quad(0 ; 0.07]\right.$ in the experiment $)$;

- when the noise level gets through the rise, it begins to decrease gradually $\left(\eta_{0} \quad[0.1 ; 1]\right.$ in the experiment);

- when the learning coefficient is too large, the noise level is not stable (see Fig. 8).

There are 2 phases of the noise level in Fig. 9: the organization process of neurons and the stabilization process of values, mentioned previously in the article. The stabilization process of values begins, when the adaptation time exceeds 1000 . 
When the initial effective width $\delta_{0}(d ; 0.1)$ distance $d$ does not achieve the middle neuron (the middle neuron is achieved in the experiment, when $d=3$ ), the islands of images are produced (see Fig. 11).

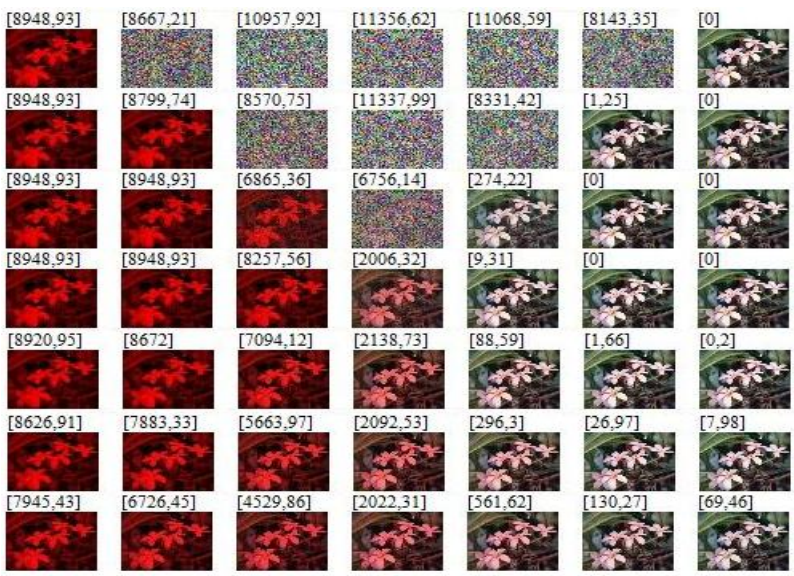

Fig. 11. The parts of the generated RGB images using the hexagonal SOM, where the numbers are MSE of the images, the first row $d=1$, the second $-d=2$, the third $-d=3$, the fourth $-d=4$, the fifth $-d=5$, the sixth $-d=6$, the seventh $-d=7$

According to the obtained information, the following conclusions are drawn:

- a better range of the learning coefficient to control the noise level is $\eta_{0} \quad[0.1 ; 1]$, when the noise level decreases gradually;

- a better range of the adaptation time to control the noise level is $t>1000$, when there is the stabilization process of values. However, it does not suit the middle neurons, because their noise level slightly changes trying to obtain the static value;
- the initial effective width must be of such a value so that the topological neighbourhood influences all neurons, when there is the winning neuron in the centre of the SOM lattice.

\section{REFERENCES}

[1] S. J. Sangwine, R. E. N. Horne, The Color Image Processing Handbook, 1st ed. London: Chapman \& Hall, 1998, 440p.

[2] С. Хайкин, Нейронные сети: полный курс, 2-е изд., испр. : Пер. с англ. - Москва: ООО «И.Д. Вильямс», 2006, 1104 с.

[3] Л. Н. Ясницкий, Введение в искусственный интеллект. Москва: Издательский центр «Академия», 2005, 176 с.

[4] B. Curry, P. H. Morgan, Evaluating Kohonen's learning rule: An approach through genetic algorithms, in European Journal of Operational Research, vol. 154, 2004, pp. 191-205.

[5] J. Pęksiński, G. Mikołajczak, Removing Noise from Digital Images Using of Mean Square Approximation, in Procedia Environmental Sciences, vol. 10, 2011, 980-985.

[6] C. C. Yang, H. Chen, K. Hong, Visualization of large category map for Internet browsing, in Decision Support Systems, vol. 35, 2003, pp. 89-102.

[7] L. Yang, Z. Ouyang, Y. Shi, A Modified Clustering Method Based on Self-Organizing Maps and Its Applications, in Procedia Computer Science, vol. 9, 2012, pp. 1371-1379.

Sergejs Kodors was born in Rezekne, Latvia. He received his bachelor degree in Information Technology from Rezekne Higher Education Institution in 2011. Now he is a master student of the study programme "Computer Systems" at Rezekne Higher Education Institution.

His research interest focuses on artificial intelligence. His current research includes image recognition and neural networks.

E-mail: sk7@@inbox.lv

Peter Grabusts was born in Rezekne, Latvia. He received his Dr.sc.ing. degree in Information Technology from Riga Technical university in 2006. Since 1996 he has been working at Rezekne Higher Education Institution. Since 2008 he is an Associate Professor at the Department of Computer Science.

His research interests include data mining technologies, neural networks and clustering methods. His current research focuses on techniques for clustering and fuzzy clustering.

E-mail: peter@ru.lv

\section{Sergejs Kodors, Pēteris Grabusts. Ar pašorganizējošās kartes palīdzību ǵenerēto RGB attēlu trokšna līmeṇa analīze}

Lai noteiktu mākslīgo neironu tîklu iespējas atpazìt attēlus, tiek izmantota metode ar nosaukumu „krusteniskā validācija”. Atbilstoši šai metodei neironu tîkla spēja atpazīt attēlus tiek izteikta kā atpazîto attēlu procents no pārbaudes kopas. Tādējādi, lai turpmāk varētu noteikt neironu tīkla spēju atpazīt attēlus ar troksni, vispirms ir jāsagatavo pārbaudes kopa ar trokšñainiem attēliem. Šī problēma kḷūst aktuāla, kad pētnieka rīcībā ir tikai attēli bez trokšna. Tad ir nepieciešams automātisks rīks, lai ǵenerētu attēlus ar troksni. RGB attēlus ar troksni var ġenerēt, izmantojot Kohonena pašorganizējošās kartes (SOM). Pētījuma mērḳis bija izpētît RGB attēla trokšna līmeni atkarībā no SOM parametriem: apmācības koeficienta, apmācības laika un slīpuma koeficienta. Rakstā ir aprakstīta visa nepieciešamā teorija, kā ġenerēt RGB attēlus ar troksni, izmantojot SOM: SOM sastāvošie elementi, SOM apmācības process, SOM īpašība, kas tiek izmantota RGB attēla ar troksni generēšanai, asociācijas starp RGB attēlu un neironu svariem izveidošana, trokšņa līmeṇa aprēḳināšanas formula un SOM sešstūrveida struktūras apraksts, kuru izmantojot, var generēt ar troksni novirzītus attēlus katrā krāsas komponentē. Pamatojoties uz šo informāciju, tika organizēts eksperiments. Eksperimentā tika izmantots viendimensijas SOM ar 5 neironiem, lai aprakstītu trokšņa līmeņa atkarību no SOM parametriem. Tāds neironu skaits tika izvēlēts, lai apkopotu rezultātus uz loǵiskām neironu grupām. Lai iegūtu papildinformāciju par slīpuma koeficienta ietekmi uz trokšņa līmeni, eksperimenta modelis tika paplašināts līdz 7 neironiem. Pamatojoties uz eksperimenta rezultātiem, tika izstrādātas rekomendācijas (noteikti SOM parametru diapazoni) trokšṇa lìmeņa regulěšanai.

\section{Сергей Кодорс, Петерис Грабустс. Анализ уровня шума RGB изображений, созданных посредством самоорганизующихся карт}

Чтобы выразить, насколько эффективно нейросеть распознает изображения, используется метод перекрестной проверки. Опираясь на данный метод, эффективность нейросети определяется как процент корректно опознанных изображений. Следовательно, чтобы выразить способность распознавать зашумленные изображения, необходимо подготовить коллекцию изображений с заданным диапазоном шума. Данное условие требует наличия автоматической системы для генерации изображений с шумом, когда в распоряжении исследователя есть только изображения без шума. RGB изображения с шумом можно сгенерировать посредством самоорганизующихся карт Кохонена (SOM). Целью данной работы является исследование зависимости уровня шума от параметров самоорганизующихся карт Кохонена: количества итераций обучения, скорости обучения и эффективной ширины. В данной работе предоставлена вся необходимая информация для генерации RGB изображений с шумом посредством использования SOM: описание SOM элементов, процесс обучения SOM, создание ассоциации между RGB изображением и весами синапсов нейрона, расчет уровня шума и шестиугольная SOM для генерации RGB изображений с отклонением цвета в сторону каждого цветового компонента. Для исследования зависимости уровня шума от параметров SOM была использована одномерная самоорганизующаяся карта из 5 нейронов. Модель из 5 нейронов была выбрана с целью объединить результаты в логические группы нейронов. Чтобы извлечь дополнительную информацию о влиянии эффективной ширины на уровень шума, экспериментальная модель была расширена до 7 нейронов. На основании полученных результатов были составлены рекомендации: какие диапазоны значений параметров самоорганизующийся карты использовать для контроля уровня шума RGB изображений. 